\title{
Endoglucanase activity in Neoteredo reynei (Bivalvia, Teredinidae) digestive organs and its content
}

\author{
Daniela Toma de Moraes Akamine ${ }^{1}$. Daniel de Almeida Cozendey da Silva ${ }^{1}$. Gabriela de Lima Câmara ${ }^{1}$. \\ Thayane Vieira Carvalho ${ }^{1} \cdot$ Michel Brienzo ${ }^{2}$ (I)
}

Received: 27 May 2017 / Accepted: 31 May 2018 / Published online: 1 June 2018

(c) Springer Science+Business Media B.V., part of Springer Nature 2018

\begin{abstract}
Cellulolytic enzymes have been studied in several organisms, such as insects, molluscs and other organisms, which can have enzymes endogenously produced or by symbiotic microorganisms. These enzymes are responsible for breaking down the cellulosic material upon which these organisms feed, probably with the aim of assimilating the sugars and nutrients. As Teredinidae bivalves grown in mangrove trees, this study aimed to measure endo- $\beta-1,4$-glucanase activity in different organs and its content. Endo- $\beta-1,4$-glucanase activity was detected in different organs of the Teredinidae bivalves, including gills and digestive organs tissues and its content. Moreover, organisms such as teredinids grow up inside wood and this process could perhaps be related to creating growth space. All the endoglucanase extracts, from organs tissues and contents, showed maximum activity at $40{ }^{\circ} \mathrm{C}$. The maximum activity was observed at $\mathrm{pH} 5.5$ for all the extracts, except for intestine tissue, which maximum was at $\mathrm{pH}$ 6. Moreover, some of the extracts showed a different profile of the activity as a pH influence, suggesting different distribution of enzymes over the digestive system of the teredinids. The results suggested that the endo- $\beta$-1,4-glucanase from Teredinidae could be applied in process that requires low temperature, such as, simultaneous saccharification and fermentation, since it presents lower optimum temperature in comparison to enzymes from terrestrial microorganisms.
\end{abstract}

Keywords Teredinidae $\cdot$ Cellulases $\cdot$ Wood digestion $\cdot$ Endo- $\beta-1,4$-glucanase $\cdot$ Optimum activity

\section{Introduction}

The Teredinidae family is a specialized bivalve, which bore and digest the wood to live inside trunks. Most of them are marine tropical molluscs found around the world, mainly in shallow environments. The digestion of wood in the shipworms, as they are commonly known, begins when the shell scrapes the wood, generating small particles that go into the mouth, pass through the esophagus and reach the stomach. In some teredinid species, there is only one part of the stomach, which is circular (Lopes et al. 2000). In

Michel Brienzo

michel.brienzo@unesp.br

1 Laboratory of Biotechnology (Labio), Metrology Applied to Life Science Division - National Institute of Metrology, Quality and Technology (Inmetro), Duque de Caxias, RJ, Brazil

2 Bioenergy Research Institute (IPBEN), Universidade Estadual Paulista (UNESP), Rio Claro, SP, Brazil others, the stomach is divided into three parts, one circular and other two elongated (Lopes and Narchi 1998). In the stomach, wood particles receive the enzymes from the digestive glands, whose ducts deflate into these organs. From the stomach, the material (wood particles) goes to the appendix, and it can stay there for a long time. From the appendix, it returns to the stomach and is conducted to the intestine. The material passes throughout the intestine length and flows into the anal canal. In some species, such as the Neoteredo reynei, the anal canal is closed by a valve and the wood particles remain in this organ for a long time while they go through the whole length of the organ. Finally, the material is ejected as feces, through an exhalant siphon, into the environment. A detailed illustrated anatomy of the $N$. reynei has been published elsewhere (Lopes et al. 2000). The material would be digested during its journey across the digestive system, however the digestion of wood in the appendix and anal canal was not found in some organisms, such as $N$. reynei (Lopes et al. 2000). 
Differently of termites, shipworms have few microorganisms in their digestive systems. Despite being in the gills, there are registers of some populations of a cellulolytic and nitrogen-fixing bacteria found in several species of shipworms (Betcher et al. 2012). It is the Teredinibacter turnerae, a kind of gamma proteobacterium that makes it possible for these molluscs to use nitrogen compounds that do not exist in wood and also to digest wood particles through the secretion of enzymes that break the cellulose chains (Waterbury et al. 1983; Iman et al. 1993; Distel et al. 2002; Distel 2003; Xu and Distel 2004; Yang et al. 2009; O'Connor et al. 2014).

Some studies indicated that molluscs can produce enzymes for wood decay. However, other studies point to a symbiotic relation with cellulolytic microorganisms in some spcies, such as Mytilus, Corbicula, and Haliotis (Xu et al. 2001; Suzuki et al. 2003). Some cellulase and protease enzymes produced by these endosymbiotic bacteria were identified and characterized (Greene et al. 1988; Iman et al. 1993; Xu and Distel 2004), but there is no previous register of cellulase enzymes produced endogenously or by other symbionts in the digestive system of teredinids.

Cellulase enzymes are a group of at least three enzymes: endo- $\beta$-1,4-glucanase (EC 3.2.1.4), exo- $\beta-1,4$-glucanase (EC 3.2.1.91), and $\beta$-glucosidases (EC 3.2.1.21). The endo$\beta$-1,4-glucanase randomly attacks the internal and amorphous chain, the glycosidic bonds of cellulose, releasing oligomers, which are substrates for exo- $\beta$ - 1,4 -glucanase to act on the ends of the chain and to release cellobiose; the $\beta$-glycosidases act specifically on the cellobiose (glucose disaccharide), producing glucose (Lynd et al. 2002). Cellulases have been increasingly receiving research attention and interest because of their potential in converting the biomass into bioethanol and also in processes that use fermentable sugars. There is a growing interest in finding new enzymes sources with improved catalytic activity. Furthermore, information about endoglucanase activities could bring useful insights when it comes to the Teredinidae as a biotechnological system of cellulosic material degradation. Moreover, enzymes with specific characteristics that can be find in different environmental could benefit biotechnology process such as biomass conversion. Therefore, the main objective of this work was to investigate the endo- $\beta$-1,4-glucanase profile over the digestive system of the $N$. reynei, a common shipworm found in the mangroves of Brazil.

\section{Materials and methods}

\section{Collection of the $N$. reynei specimens}

The animals were collected in the mangrove of Barra de Guaratiba, Rio de Janeiro city, State of Rio de Janeiro, in
November, 2012 (coordinates $22^{\circ} 59^{\prime} \mathrm{S}, 43^{\circ} 36^{\prime} \mathrm{W}$ ). The logs/ trunks were taken to the laboratory at the National Institute of Metrology, Quality and Technology (Inmetro), and the specimens were carefully removed from the wood. NeOteredo reynei specimens were rinsed with sterile seawater before the dissection step.

\section{Dissection and preparation of extracts}

Three $N$. reynei specimens were dissected under a stereoscope microscope (Labomed Luxeo 4D) with sterile seawater, and the organs and their contents were separated. It was established that organ is the entire tissue (content free); and content is the liquid and particles inside of the organ. Considering this the organs where the wood particles could be digested, through enzymatic action, it has been chosen to perform the study with raw extracts of: appendix content; appendix tissue; anal canal content; anal canal tissue; intestine content and tissue; digestive diverticula; gills; stomach content; and stomach tissue. All the samples (organs or content) were collected in a $10 \mathrm{~mL}$ tube and the volume was completed to $4 \mathrm{~mL}$ with sodium citrate buffer $\mathrm{pH} 5.4$, with exception of the anal canal content that volume was completed to $20 \mathrm{~mL}$ with buffer due to higher content compared to other organs content. The organs tissue was smashed with a rod until complete defragmentation. The samples were centrifuged (Beckman Coulter ${ }^{\mathrm{TM}}$ Microfuge ${ }^{\circledR} 22 \mathrm{R}$ ) for solids separation at $10,000 \times \mathrm{g}$ for $5 \mathrm{~min}$, volume corrected to $4 \mathrm{~mL}$ with the same buffer, and stocked at $-20^{\circ} \mathrm{C}$ for further studies.

\section{Endo- $\beta$-1,4-glucanase assays}

The activity of endo-1,4- $\beta$-D-glucanase (endoglucanase) was determined by reducing the sugar content released by carboxymethylcellulose (CMC) solutions incubated with enzyme preparations at $50{ }^{\circ} \mathrm{C}$, pH $5.4(50 \mathrm{mM}$ citrate-phosphate buffer). The reducing sugars were measured by the dinitrosalicylic acid (DNS), method standardized with glucose (Miller 1959). For this assay, 1 IU of endoglucanase activity is defined as the amount of enzyme catalyzing the release of $1 \mu \mathrm{mol} / \mathrm{min}$ of glucose. The activity was shone also based on the amount of total protein in solution as IU/ $\mathrm{mg}$ of protein. The assay was performed with $20 \mu \mathrm{L}$ of raw extracts and $180 \mu \mathrm{L}$ of $0.44 \%$ ( $4.4 \mathrm{~g} / \mathrm{L}$ ) CMC solution in microtubes and incubated at $50{ }^{\circ} \mathrm{C}$ for $60 \mathrm{~min}$, using a ThermoShaker (Benchmark Scientific, Model H 5000-H). The reaction was interrupted by the addition of $460 \mu \mathrm{L}$ of DNS. The tubes were incubated at $100{ }^{\circ} \mathrm{C}$ for $5 \mathrm{~min}$ and, after cooling, analyzed in a spectrophotometer (Bioteck Synergy 2 ) at $540 \mathrm{~nm}$. The absorbance was converted to glucose concentration by using an analytical curve $(1-5 \mu \mathrm{mol} / \mathrm{mL})$. The total protein amount was determined by using the Coomassie 
blue method described by Bradford, using bovine serum albumin as a standard (Bradford 1976).

\section{Temperature and $\mathrm{pH}$ influence on the activity of endo- $\beta-1,4$-glucanase}

Endoglucanase activity was determined by using an extract of anal canal content to verify the effect of the temperature and $\mathrm{pH}$. Anal canal content was used due the higher volume of enzymatic extract. The previously described endoglucanase assay was performed at temperatures of 20,30, 40,50 , and $60^{\circ} \mathrm{C}$, and $\mathrm{pH} 5.4$, in $50 \mathrm{mM}$ citrate-phosphate buffer. The endoglucanase thermostability was determined at $50{ }^{\circ} \mathrm{C}$ because of the usual condition of the enzymatic hydrolysis. The residual enzyme activity was measured by incubating the enzymatic extract (1.5 $\mathrm{mL}$ in a sealed tube) up to $72 \mathrm{~h}$, in the absence of substrate. Each of the sample at different periods, performed in triplicate, was done in individual tube, and the residual activity of the endoglucanase was assayed again under standard conditions.

The effect of the $\mathrm{pH}$ was determined at $\mathrm{pH} 4-7$ in a $50 \mathrm{mM}$ citrate-phosphate buffer, and at $\mathrm{pH}$ 7-9 in the sodium-phosphate buffer. The assays were performed at standard conditions.

\section{SDS-gel electrophoresis}

The molecular weight of studied proteins was determined by SDS-gel electrophoresis on a $12 \%$ polyacrylamide gel. A high molecular weight range was used for calibration Kaleidoscope Prestained (BioRad-161-0324). The gels were stained with Coomassie brilliant blue R-250 (0.2\% in $40 \%$ methanol and $10 \%$ acetic acid). For the preparation of SDS-PAGE, $50 \mu \mathrm{g}$ of protein was applied to the digestive diverticula, anal canal tissue, appendix tissue and stomach contents. The content of the anal canal was applied at a concentration of $22.5 \mu \mathrm{g}$ of protein.
Zymogram gel was prepared by the addition of $0.01 \%$ of 4 -methylumbelliferyl- $\beta$-D-glucopyranoside or 4 -methylumbelliferyl- $\beta$-D-cellobioside to the polyacrylamide gel. The gels were incubated at $37^{\circ} \mathrm{C}$ for $30 \mathrm{~min}$, and the zones of clearance were visualized with ultravilolet (Cheng and Chang 2011).

\section{Enzymatic hydrolysis}

Enzymatic hydrolysis was performed with $2 \%$ carboximethilcellulose (CMC), by incubating $0.1 \mathrm{~g}$ of CMC in $5 \mathrm{~mL}$ of $0.05 \mathrm{M}$ citrate buffer (pH 5), in $15 \mathrm{~mL}$ flasks, at $50{ }^{\circ} \mathrm{C}$, and with constant agitation (in an orbital shaker, at $170 \mathrm{rpm}$ ). Reactions mixtures contained $0.15 \mathrm{IU} / \mathrm{g}$ CMC (Celluclast 1.5 L, Novozymes), and/or $0.15 \mathrm{IU} / \mathrm{g}$ cellobiase ( $\beta$-glucosidase, Novozym 188-Novozymes), and or $0.15 \mathrm{IU} / \mathrm{g}$ anal canal content extract. The reaction was performed with commercial enzyme Celluclast and canal anal content extract separated, and also combined with cellobiase. The enzymatic digestibility of CMC was calculated from the glucose yield (measured by HPLC) after different reaction times $(0,24,48$ and $72 \mathrm{~h})$. Enzymatic hydrolysis assays were performed in experimental triplicates, and averaged results were reported. The conversion yield was calculated based on the glucose and cellobiose released.

\section{Results}

Among the organs, the digestive diverticula showed the highest protein concentration: $1.23 \mathrm{mg} / \mathrm{mL}$ (Table 1). The digestive diverticula stocks enzymes and unload them into the stomach, probably decreasing the enzyme concentration by mixing them with particles of wood. The protein concentration increased in the appendix and intestine, probably due to microorganisms that grow in these organs. The anal canal, as a long tube, could cause the protein to dilute, decreasing its concentration. The enzyme concentration could not be
Table 1 Endoglucanase activity in the extracts from $N$. reyne $i$ organ tissues and contents

\begin{tabular}{llll}
\hline Sample & $\begin{array}{l}\text { Endoglucanase }(\mathrm{IU} / \\
\mathrm{mg})\end{array}$ & $\begin{array}{l}\text { Endoglucanase }(\mathrm{IU} / \\
\mathrm{mL})\end{array}$ & Protein $(\mathrm{mg} / \mathrm{mL})$ \\
\hline Gill & $2.75 \pm 0.04$ & $0.74 \pm 0.01$ & $0.27 \pm 0.02$ \\
Normal digestive diverticula & $0.36 \pm 0.01$ & $0.44 \pm 0.03$ & $1.23 \pm 0.06$ \\
Specialized digestive diverticula & $1.14 \pm 0.15$ & $0.47 \pm 0.06$ & $0.41 \pm 0.02$ \\
Stomach tissue & $1.65 \pm 0.10$ & $0.51 \pm 0.03$ & $0.31 \pm 0.03$ \\
Stomach content & $1.15 \pm 0.01$ & $0.49 \pm 0.03$ & $0.43 \pm 0.04$ \\
Appendix tissue & $1.26 \pm 0.05$ & $0.50 \pm 0.02$ & $0.40 \pm 0.01$ \\
Appendix content & $1.28 \pm 0.22$ & $0.38 \pm 0.06$ & $0.30 \pm 0.02$ \\
Intestine & $3.65 \pm 0.15$ & $0.58 \pm 0.02$ & $0.16 \pm 0.05$ \\
Anal canal tissue & $0.33 \pm 0.01$ & $0.07 \pm 0.01$ & $0.21 \pm 0.03$ \\
Anal canal content & $0.02 \pm 0.01$ & $0.01 \pm 0.01$ & $0.48 \pm 0.05$ \\
\hline
\end{tabular}


distinguished from the total protein amount that was determined. However, it is expected to find a higher concentration of enzymes than of other proteins, considering the role they play in the material degradation. Interestingly, the gill, which is not an organ related to digestion, showed the highest endoglucanase activity, probably because its enzymes can be translocated to gut (O'Connor et al. 2014).

\section{Enzymatic activities in the Teredinidae digestive system}

To understand the enzyme presence, several of the $N$. reyne $i$ digestive organs were separated into content and tissue and the enzymatic activity of endoglucanase was determined. The endoglucanase activity was found in tissues of several organs, such as stomach tissue, appendix tissue and anal canal tissue (Table 1). The highest endoglucanase activity was found in the gill tissue, with $2.75 \mathrm{IU} / \mathrm{mg}$. Among the digestive organs, the intestine showed higher endoglucanase activity: $3.65 \mathrm{IU} / \mathrm{mg}$, and also per volume, showing the activity of $0.58 \mathrm{IU} / \mathrm{mL}$ (Table 1 ).

The lower tissue and organ content activity found in the anal canal were 0.33 and $0.02 \mathrm{IU} / \mathrm{mg}$, respectively. The enzymatic activity followed an increasing path until the intestine, whereas it decreased in the anal canal. The specific activity of endoglucanase was higher for the intestine (3.65 IU/mg), gill (2.75 IU/mg), stomach tissue (1.65 IU/ $\mathrm{mg})$, appendix tissue $(1.26 \mathrm{IU} / \mathrm{mg})$ and also appendix content (1.28 IU/mg) (Table 1$)$.

\section{Temperature and $\mathrm{pH}$ effect on the endo- $\beta-1,4-$ glucanase activity}

The effects of the temperature on the endoglucanase activity of raw extracts from different digestive organs of Teredinidae were measured. All the enzymatic extracts of the organs have shown a similar optimum temperature: $40{ }^{\circ} \mathrm{C}$ (Fig. 1). The endoglucanase activity has been influenced by the temperature. Enzymatic extracts from the intestine content were more sensible to temperature, showing lower activities for assays at 30 and $60^{\circ} \mathrm{C}$ (lower than $30 \%$ of total activity) (Fig. 1). The test at $50{ }^{\circ} \mathrm{C}$ showed $70 \%$ percent of the total activity. Enzymatic extracts from anal canal content, digestive diverticula, and stomach tissue showed a similar profile of endoglucanase activity according the effects of the temperature. With slight differences, appendix content showed more affected endoglucanase activity if compared to the described group.

In spite of the optimum temperature being around $40{ }^{\circ} \mathrm{C}$, the thermal stability was determined at $50{ }^{\circ} \mathrm{C}$ due to be compared to fungi endoglucanase. Also, this is the most used temperature for studies that aim to determine the enzymatic activity and the enzymatic hydrolysis (saccharification) (Shimizu et al. 2018; Wallace et al. 2016; Brienzo et al. 2008). The enzymatic activity of the endoglucanase continuously decreased for $20 \mathrm{~h}$, thereafter it stabilized at around $20 \%$ of the total activity (Fig. 2). The half-life of the endoglucanase at $50{ }^{\circ} \mathrm{C}$ were determined as $11 \mathrm{~h}$.

The effects of the $\mathrm{pH}$ on the endoglucanase activities of raw extracts from different digestive organs of Teredinidae were measured. The optimum $\mathrm{pH}$ was between 5.5 and 6 for endoglucanase in extracts from anal canal tissue, digestive diverticula, stomach content, and canal anal content. Differently, the endoglucanase from intestine content showed
Fig. 1 Temperature effect on the endoglucanase activity in extracts from $N$. reynei organs

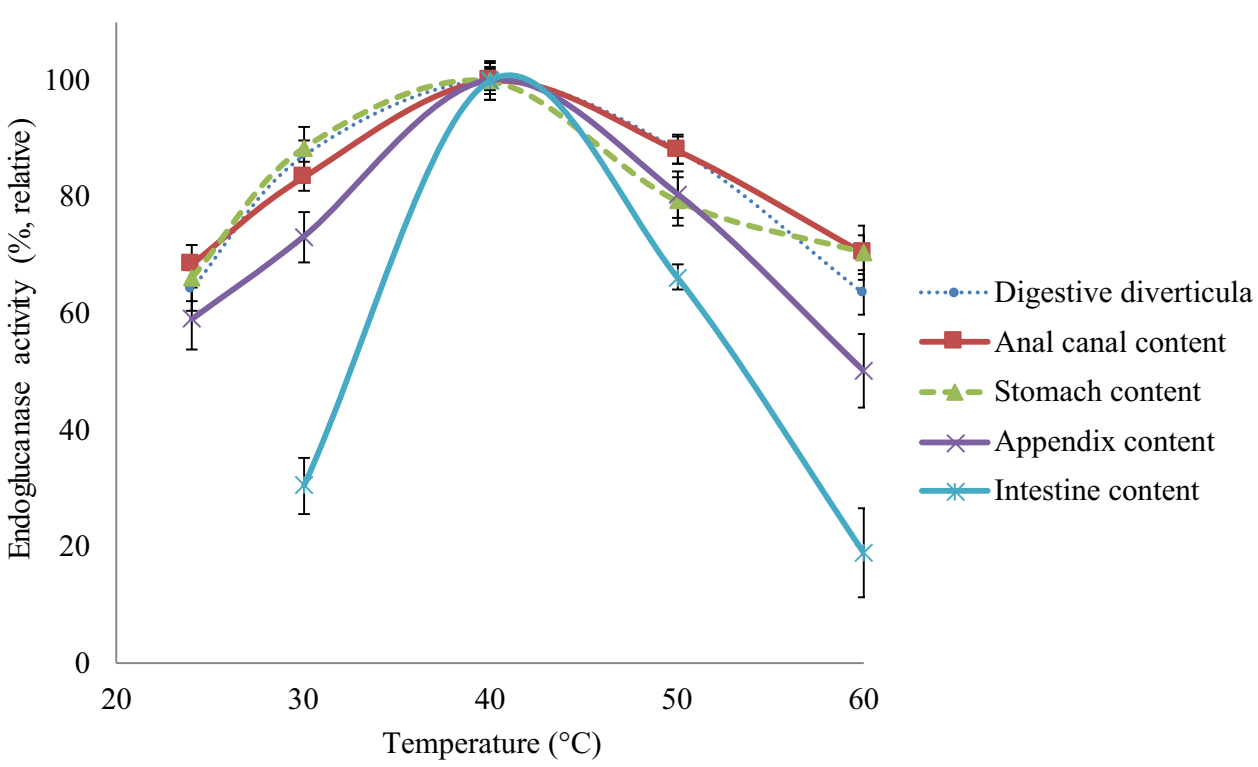


Fig. 2 Thermal stability of endoglucanase activity in extracts from $N$. reynei canal anal content

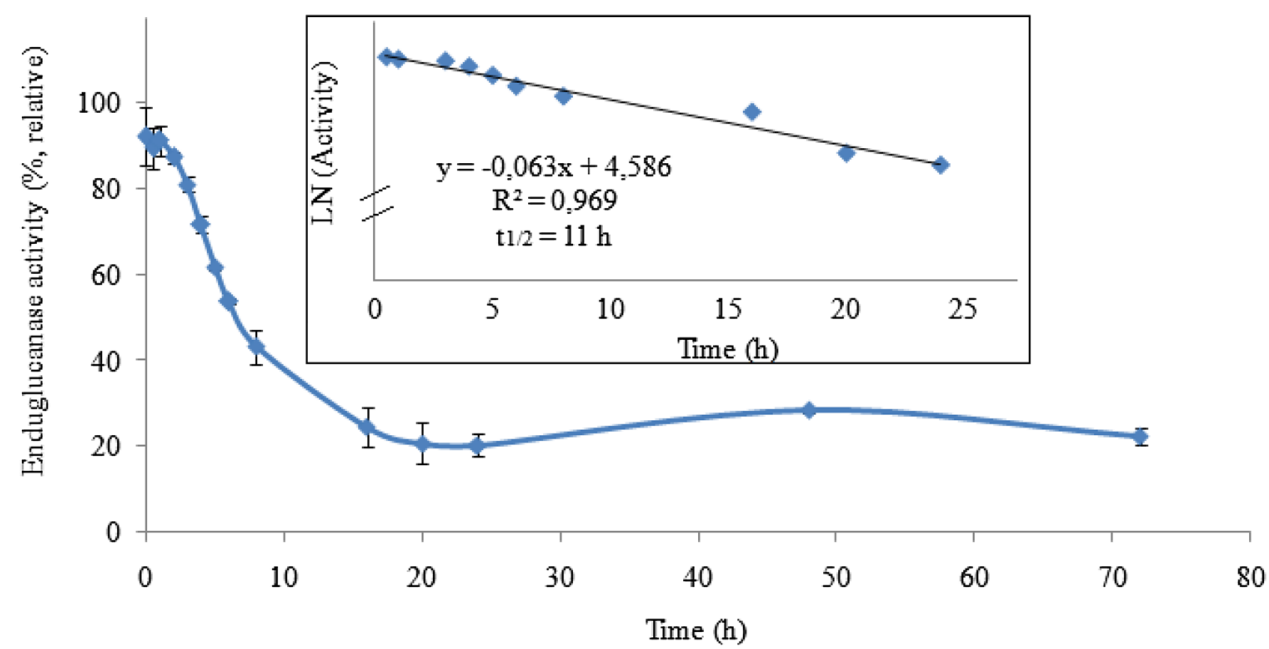

Fig. 3 Effect of $\mathrm{pH}$ on the endoglucanase activity in extracts from $N$. reynei organs

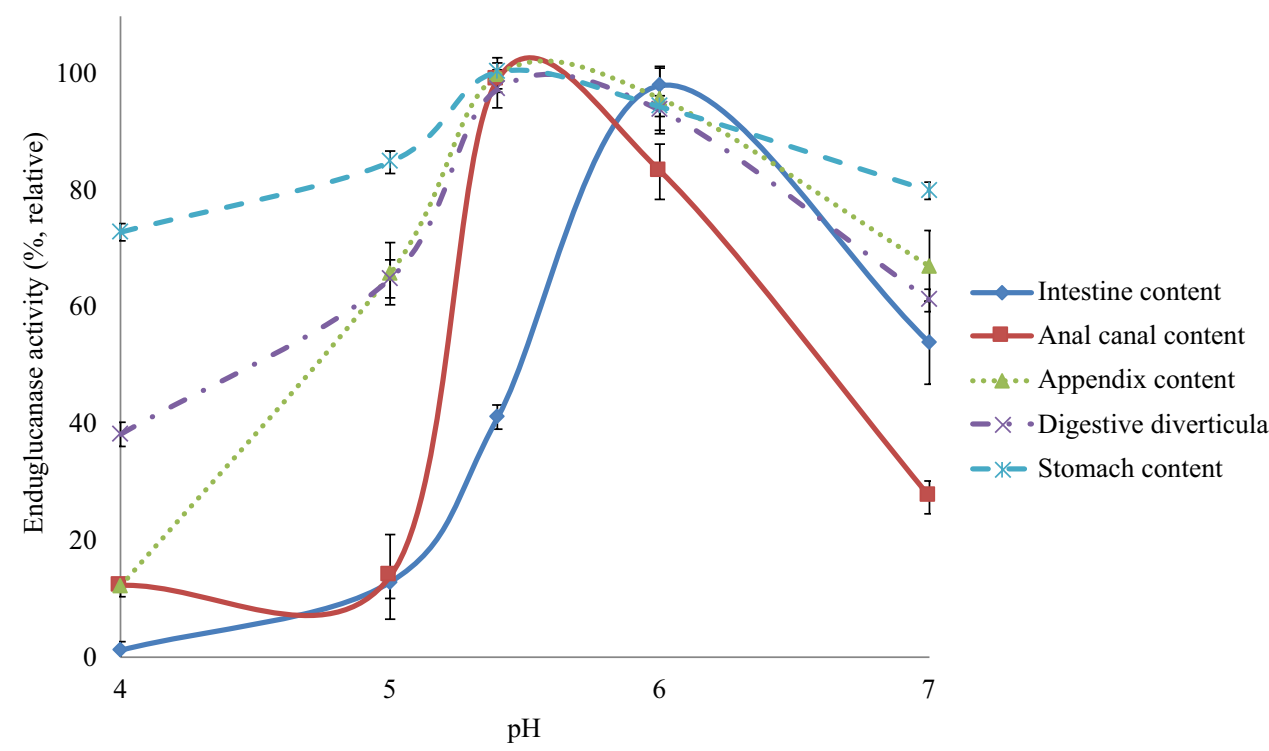

optimum pH at 6 (Fig. 3). It was possible to observe that all the endoglucanase activities were more stable at alkaline than at acidic $\mathrm{pH}$. Extracts from anal canal content and stomach content showed an optimum region between 6.5 and 6 , with a slow decrease in the activity for $\mathrm{pH}$ higher than 6 .

\section{Electrophoresis study of enzymes}

The crude enzymatic extracts were analyzed by electrophoretic techniques. SDS-PAGE analysis revealed a similar number of proteins with a similar molecular weight in all samples (Fig. 4). The result indicates that there is a more intense band, of molecular weight of approximately $17.4 \mathrm{kDa}$ in all samples. Other lower intense bands of molecular weights ranging from 32.1 to $48.2 \mathrm{kDa}$ can also be seen in all the samples. However, it is more intense in the appendix tissue and less in the anal canal content. Probably,

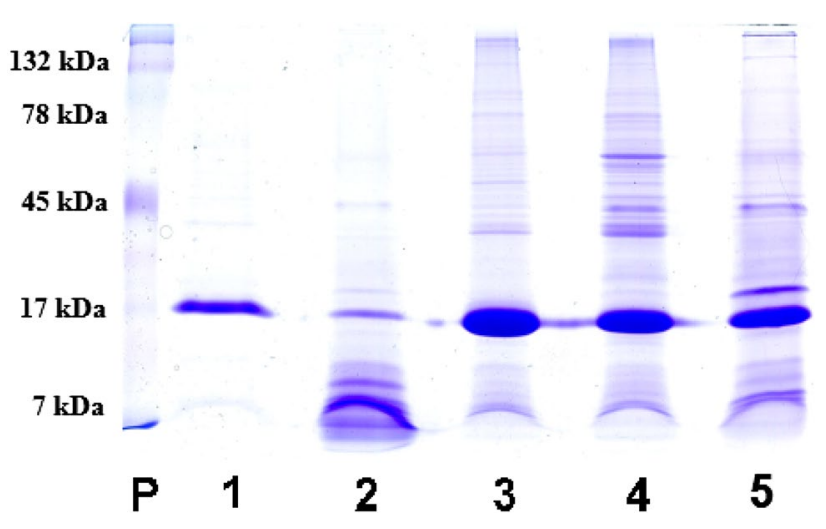

Fig. 4 SDS-gel electrophoresis of the crude enzymatic extract in $12 \%$ polyacrylamide gel extracts. Sample applied contained $50 \mu \mathrm{g}$ of protein, except for sample 1, where $22.5 \mu \mathrm{g}$ of protein was applied. Sample: 1-anal canal content; 2-digestive diverticula; 3-anal canal tissue; 4-appendix tissue; 5-stomach content 
the contents of the anal canal presented the same pattern of protein distribution, as it is with lower concentration of protein compared to the other samples.

The zymogram of enzymatic activity of $\beta$-glycosidase indicated the presence of an enzyme with molecular weight of $129.3 \mathrm{kDa}$ (Fig. 5a). The extract corresponding to the anal canal content was concentrated, and all samples had an equal amount of protein applied into the gel. Only the samples corresponding to the digestive diverticula and to the anal canal tissue had lower intense bands in relation to the other samples.

The enzyme activity zymogram of exoglucanase indicated the presence of an enzyme with a molecular weight of $20 \mathrm{kDa}$ (Fig. 5b). All the organs analyzed presented the band corresponding to this enzyme, however only one band was detected in each crude extract. The bands corresponding to the contents and tissue of the anal canal proved to be lower intense when compared to the others, indicating a lower activity of this enzyme in this organ.

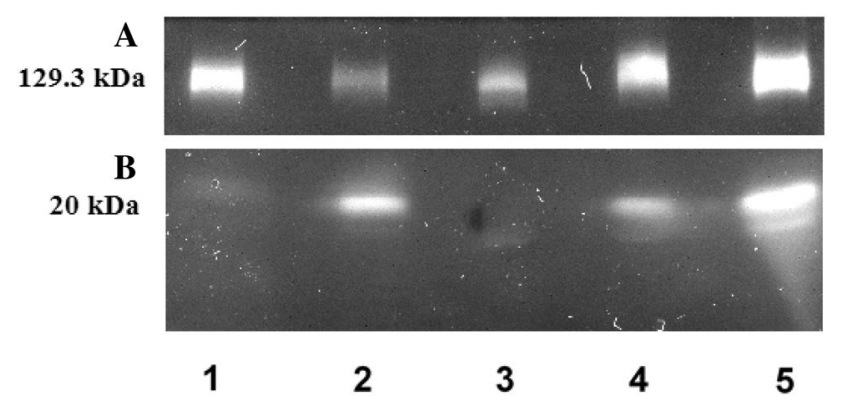

Fig. 5 Zymogram of crude enzymatic extract for $\beta$-glucosidase (a) and exoglucanase (b) activity in $8 \%$ polyacrylamide gel. Assay with $40 \mu \mathrm{g}$ of protein per sample. Sample: 1-anal canal content; 2digestive diverticula; 3-anal canal tissue; 4-appendix tissue; 5stomach content

\section{Enzymatic hydrolysis}

The anal canal content was applied in the enzymatic hydrolysis of CMC comparatively to commercial enzymatic extracts. The enzymatic hydrolysis was performed with a soluble cellulose derivative, using low amount of enzyme activity $(0.15 \mathrm{IU} / \mathrm{g}$, for all the enzymatic extracts). The conversion of CMC into cellobiose was similar to anal canal content extract and commercial enzyme (Celluclast) (Fig. 6). The glucose release was three times higher to the commercial extract compared to the anal canal content extract. The enzymatic hydrolysis was performed also adding commercial $\beta$-glucosidase extract (Novozym-Novozymes). The glucose release adding $\beta$-glucosidase provided different results comparing commercial and anal canal content extract. The anal canal content supplemented with $\beta$-glucosidase resulted in higher glucose yield compared to commercial extract supplemented.

\section{Discussion}

The protein concentration increased in the appendix and intestine, probably due to microorganisms that grow in these organs. The anal canal, as a long tube, could cause the protein to dilute, decreasing its concentration. The enzyme concentration could not be distinguished from the total protein amount that was determined. However, it is expected to find a higher concentration of enzymes than of other proteins, considering the role they play in the material degradation. Teredinids feeding is based on wood particles, but also on organic material in suspension in the surrounding water (Turner 1996). Paalvast and Velde (2013) suggested, specifically for Teredo navalis, that the main source of carbon, instead of wood, as it would be expected, comes from filter
Fig. 6 Enzymatic hydrolysis using anal canal content extract from Neoteredo reynei and commercial enzymes (Cellulcast, supplemented with Novozym-Novozymes) $0.15 \mathrm{IU} / \mathrm{g}$ os substrate

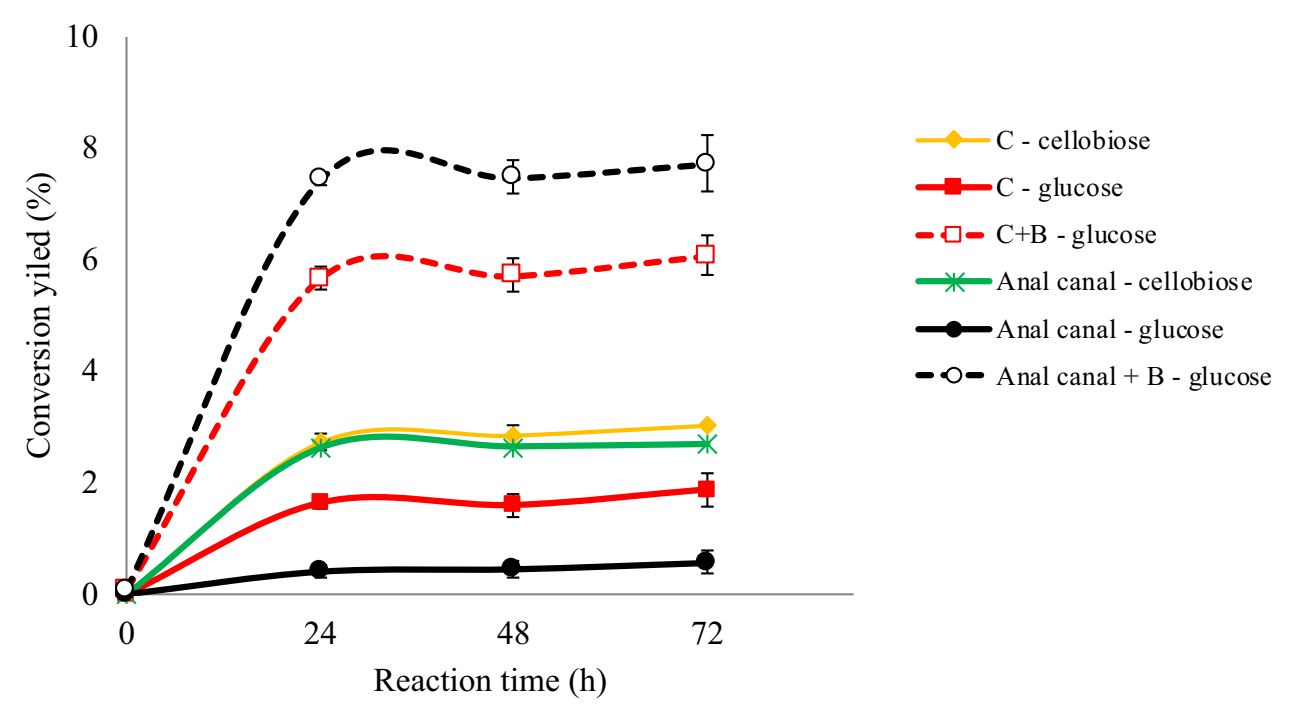


feeding via siphons. However, the symbiotic system provides enzymatic tools of wood degradation (Betcher et al. 2012). At least, the presence of enzymes could not be ignored as a contributor to processing wood along the digestive system. To understand the enzyme presence, several of the $N$. reynei digestive organs were separated into content and tissue and the enzymatic activity of endoglucanase was determined.

The endoglucanase activities found in stomach tissue, appendix tissue and anal canal tissue (Table 1) suggest that the wood degradation could be more relevant than just being processed in order to secrete as feces. The wood degradation is enhanced with symbiotic association with microorganisms or groups of microorganisms. In fact, endoglucanase activity was found in all of the organs studied, including the gills (Table 1). Moreover, there is a study suggesting that enzymes are translocated from the gills to the stomach (O'Connor et al. 2014). Trindade-Silva et al. (2009) reported the presence of eubacteria in the intestine and in the gills of $N$. reynei, but there is no clear understanding of the host's biology.

The specific endoglucanase activity was higher in the tissue than in the content for the stomach and anal canal. The activity was similar for the appendix tissue and content (Table 1). Among the tissue and organ content the intestine was higher endoglucanase activity. The intestine higher endoglucanase activity is interesting since some authors have suggested that the appendix is the wood digestion site (Cragg et al. 2015; O'Connor et al. 2014; Elshahawi et al. 2013). In N. reynei, the wood particles stayed for a long time in the appendix (Lopes et al. 2000), allowing the enzymes to act, and the products of digestion to be absorbed. This was suggested by the microvilli epithelium found in the appendix (Lopes et al. 2000). Otherwise, a poor bacteria community has been reported in the appendix, but a very well-developed bacteria community was found in the intestine of five species of shipworms (Betcher et al. 2012). The endoglucanase activities found can suggest that it is possible to run a biochemical breakdown of wood cellulose and of the organic matter. Extracts from the bivalve Corbicula japonica have shown an endoglucanase activity of $0.80 \mathrm{IU} / \mathrm{mg}$. Species that degrade organic matter from marine origin, such as Ruditapes philippinarum and Mactra veneriformis, have shown an endoglucanase activity of $0.30 \mathrm{IU} / \mathrm{mg}$ (Sakamoto and Toyohara 2009). Digestive tracts tissue homogenates of Bankia gouldi, a shipworm, have shown an endoglucanase activity of $0.023 \mathrm{IU} / \mathrm{mg}$, with an enzymatic hydrolysis rate that is comparable to the ones found in Trichoderma viride and Aspergillus niger (Dean 1978).

The relative lower optimum temperature of $40^{\circ} \mathrm{C}$ (Fig. 1), when compared to fungi endoglucanases, is probably related to the environmental characteristics of the teredinids. The molluscs were collected on the mangrove, where the common water temperature probably is not higher than $25{ }^{\circ} \mathrm{C}$.
The mangrove water temperature depends on several factors, and a range of $17-25{ }^{\circ} \mathrm{C}$ has been reported for a mangrove in some countries (Moraes et al. 2015). The difference on the temperature effects on the endoglucanase activity may suggest that this enzyme could be from a different microorganism, or from a different symbiotic system. The Teredinibacter turnerae isolated from Lyrodus pedicellatus gills was cultivated and its endoglucanase was characterized. The optimum temperature for this enzyme was $50{ }^{\circ} \mathrm{C}$, with a strong decrease in the residual activity at temperatures lower than $40{ }^{\circ} \mathrm{C}$ and higher than $60{ }^{\circ} \mathrm{C}$ (Xu and Distel 2004). The half-life of the endoglucanase at $50^{\circ} \mathrm{C}$ were $11 \mathrm{~h}$ what is a range common for microorganisms classified as mesophilic; however, a higher stability could be observed for enzymes from thermostable microorganisms (Wallace et al. 2016; Heidorne et al. 2006).

Endoglucanase from intestine content has shown optimum $\mathrm{pH}$ at 6 , differently that found in extracts from anal canal content and tissue, digestive diverticula, and stomach content that showed 5.5. The endoglucanase from Teredinibacter turnerae isolated from Lyrodus pedicellatus gills has shown optimum $\mathrm{pH}$ between 6 and 7, with a higher sensibility for extreme $\mathrm{pH}$ (Xu and Distel 2004). The extracts from digestive diverticula and stomach content have shown higher endoglucanase activity at acidic $\mathrm{pH}$ than the other extracts. The different optimum $\mathrm{pH}$ between digestive diverticula and stomach and the other organs content showed that the endoglucanase is different, and possibly, there are from different microorganisms or groups of microorganisms populating the organs (Cragg et al. 2015; Betcher et al. 2012). The rumen degradation of cellulosic material is associated to microorganisms that are related to protozoa, fungi and bacteria. Among the several microorganisms are common Ruminococcus flavefaciens, Prevotella bryantii and Pseudobutyrivibrio xylanivorans. These microorganisms are specialized for exemplo on cellulosomes production, xylanases and cellulases (Zorec et al. 2014). Termites are adapted to cellulose degradation due own mechanical and enzymatic tools, associated with the gut symbiotic (Brune 2014). Among the microorganisms in symbiosis there are different pattern related to high and low termites (Peterson and Scharf 2016). A multi microorganisms community probably benefit with the diversity of the enzyme production.

A better activity at alkaline $\mathrm{pH}$ could be positive for enzyme application if the process is carried in a condition close to neutral. Also, the optimum temperature at $40{ }^{\circ} \mathrm{C}$ could be interesting for the enzymatic hydrolysis of lignocellulosic biomass that happens simultaneously to the fermentation process (SSF) (Shane et al. 2017; Berbowska et al. 2016). Performing the enzymatic hydrolysis and fermentation in a combined step is pointed out as an advantage for the process of producing bioethanol: it increases the hydrolysis rate due to the conversion of glucose, which 
inhibits the enzyme activity; it lowers the enzyme loading and the requirements for sterile conditions because glucose is removed for fermentation (Balat et al. 2008). In order to complete the feasibility of the process, it is ideal that the enzymes act in conditions that are similar to the ones found in the fermentation microorganism. The endoglucanase activity at alkaline $\mathrm{pH}$ and optimum at a temperature of $40{ }^{\circ} \mathrm{C}$ (Figs. 2, 3) converges into the required conditions for fermentation.

The SDS-gel electrophoresis of the enzymatic extracts showed several proteins with different molecular weights (Fig. 5). These proteins appeared in a large number but with wide molecular weight distribution. The most intense band appeared with $17.4 \mathrm{kDa}$. The zymogram was applied to identify activities of other enzymes of the cellulolytic complex. Activities of the $\beta$-glucosidase and exoglucanase were observed with molecular weight of 129.3 and $20 \mathrm{kDa}$, respectively. Considering that the wood is degraded over the digestive system of the mollusc, activities of the $\beta$-glucosidase and exoglucanase were expected to be found.

Beside of the presence of the cellulolytic complex, the enzymatic hydrolysis using anal canal content extract resulted in high amount of cellobiose in the medium (Fig. 6). Probably, the enzymatic activity of the $\beta$-glucosidase was low and did not collaborate to a fast hydrolysis into glucose. In fact, the supplementation with commercial $\beta$-glucosidase resulted in improvement of the glucose release, with no cellobiose accumulation. The commercial enzyme showed better result to glucose release compared to anal canal content extract. However, the supplementation with $\beta$-glucosidase improve the anal canal content extract, reaching higher glucose yield compared to the commercial extract.

\section{Conclusion}

This study has shown endoglucanase activities in different organ tissues and in their contents. The presence of cellulase enzymes suggests the importance of processing the wood along with the Teredinidae digestive system. The enzymes present in all the organs tissues and contents points to an important role for the teredinids development collaborating to cellulosic material degrading. The enzyme function cold be related to being part of the digestive system, and also to decaying the wood, allowing the teredinids to grow inside the wood trunk and branches. The extracts from stomach contents and digestive diverticula showed more stable activity at a range of acid and alkaline $\mathrm{pH}$. An important characteristic of the Teredinae enzymes is the optimum temperature at $40{ }^{\circ} \mathrm{C}$, which is interesting for some industrial application of enzymes. Enzymatic hydrolysis showed similar results compared to commercial extracts, evidencing the potential application in cellulosic material sugars release.
Acknowledgements Authors are thankful to Fundação de Amparo à Pesquisa do Estado do Rio de Janeiro (FAPERJ), the Brazilian Council for Research and Development $(\mathrm{CNPq})$ and the National Institute of Metrology, Quality and Technology (Prometro Grant Number 550.105/2012-8) for financial support and to the Program of Human Resources Formation from Petróleo Brasileiro S.A. (Petrobrás) (PFRH-103).

\section{References}

Balat M, Balat H, Cahide O (2008) Progress in bioethanol processing. Prog Energ Combust Sci 34:551-573

BerBowska J, Pielech-Przybylska K, Balcerek M, DziekoNskaKubczak U, Patelski P, Dziugan P, Krwgiel D (2016). Simultaneous saccharification and fermentation of sugar beet pulp for efficient bioethanol production. BioMed Res Int. https://doi. org/10.1155/2016/3154929

Betcher MA, Fung JM, Han AW, O'Connor R, Seronay R, Concepcion GP, Distel DL, Haygood MG (2012). Microbial distribution and abundance in the digestive system of five shipworm species (Bivalvia: Teredinidae). PloS ONE. https://doi.org/10.1371/journ al.pone.0045309

Bradford MM (1976) A rapid and sensitive method for the quantitation of microgram quantities of protein utilizing the principle of protein dye binding. Anal Biochem 72:248-254

Brienzo M, Arantes V, Milagres AMF (2008) Enzymology of the thermophilic ascomycetous fungus Thermoascus aurantiacus. Fungal Biol Rev 22:120-130

Brune A (2014) Symbiotic digestion of lignocellulose in termite guts. Nat Rev Microbiol 12:168-180

Cheng C-L, Chang J-S (2011) Hydrolysis of lignocellulosic feedstock by novel cellulases originating from Pseudomonas sp. CL3 for fermentative hydrogen production. Bioresour Technol 102:8628-8634

Cragg SM, Beckham GT, Bruce NC, Bugg TDH, Distel DL, Dupree P, Etxabe AG, Goodell BS, Jellison J, McGeehan JE, McQueenMason SJ, Schnorr K, Walton PH, Watts JEM, Zimmer M (2015) Lignocellulose degradation mechanisms across the tree of life. Curr Opin Chem Biol 29:108-119

Dean RC (1978) Mechanisms of wood digestion in the shipworm Bankia gouldi bartsch: enzyme degradation of celluloses, hemicelluloses, and wood cell walls. Bio Bull 155:297-316

Distel DL (2003). The biology of marine wood boring bivalves and their bacterial endosymbionts. In: Goodell B, Nicholas DD, Schultz TP (eds.) Wood deterioration and preservation, vol 845. American Chemical Society Symposium Series, Washington, DC, pp 253-271

Distel DL, Beaudoin DJ, Morrill W (2002) Coexistence of multiple proteobacterial endosymbionts in the gills of wood-boring bivalve Lyrodus pedicellatus (Bivalvia, Teredinidae). Appl Environ Microbiol 68:6292-6299

Elshahawi SI, Trindade-Silva AE, Hanora A, Han AW, Flores MS, Vizzoni V, Schrago CG, Soares CA, Concepcion GP, Distel DL, Schmidt EW, Haygood MG (2013) Boronated tartrolon antibiotic produced by symbiotic cellulose-degrading bacteria in shipworm gills. PNAS 110:295-304

Greene RV, Griffin HL, Freer SN (1988) Purification and characterization of an extracellular endoglucanase from the marine shipworm bacterium. Arch Biochem Biophys 267:334-341

Heidorne FO, Magalhães PO, Ferraz AL, Milagres AMF (2006) Characterization of hemicellulases and cellulases produced by Ceriporiopsis subvermispora grown on wood under biopulping conditions. Enzyme Microb Technol 38:436-442 
Iman SH, Greene RV, Griffin HL (1993) Binding of extracellular carboxymethylcellulase activity from the marine shipworm bacterium to insoluble cellulosic substrates. App Environ Microbiol 59:1259-1263

Lopes SGBC., Narchi W (1998) Functional anatomy of Nausitora fusticula (Jeffreys, 1860) (Mollusca, Bivalvia). The Veliger 41:274-288

Lopes SGBC., Domaneschi O, Moraes DT, Morita M, Meserani GLC (2000). Functional anatomy of the digestive system of Neoteredo reynei (Bartsch, 1920) and Psiloteredo healdi (Bartsch, 1931) (Bivalvia, Teredinidae). In: Harper EM, Taylor JD, Crame JA (eds.) The evolutionary biology of the Bivalvia, vol 177. Geological Society, London, pp 257-271

Lynd LR, Weimer PJ, van Zyl WH, Pretorius IS (2002) Microbial cellulose utilization: fundamentals and biotechnology. Microbiol Mol Biol Rev 66:506-577

Miller GL (1959) Use of dinitrosalicylic acid reagent for determination of reducing sugar. Anal Chem 31:426-428

Moraes DT, Coelho-Jr C, Cruz RCG, Lopes SGBC. (2015). Ocorrência e recrutamento larval de Teredinidae (Mollusca, Bivalvia) na região do Sistema Costeiro Cananéia-Iguape, São Paulo, Brasil. Iheringia Sér Zool 105:28-34

O'Connor RM, Fung JM, Sharp KH, Benner JS, McClung C, Cushing S, Lamkin ER, Fomenkov AI, Henrissat B, Londer YY, Scholz MB, Posfai J, Malfatti S, Tringe SG, Woyke T, Malmstrom RR, Coleman-Derr D, Altamia MA, Dedrick S, Kaluziak ST, Haygood MG, Distel DL (2014). Gill bacteria enable a novel digestive strategy in a wood-feeding mollusk. Proc Natl Acad Sci 111: E5096-E5104

Paalvast P, der Velde G (2013) What is the main food source of the shipworm (Teredo navalis)? A stable isotope approach. J Sea Res 80:58-60

Peterson BF, Scharf ME (2016) Lower termite associations with microbes: synergy, protection, and interplay. Front Microbiol $7: 1-7$

Sakamoto K, Toyohara A (2009) A comparative study of cellulase and hemicellulase activities of brackish water clam Corbicula japonica with those of other marine Veneroida bivalves. J Exp Biol 212:2812-2818

Shane M, Janice P, Zhanying Z, William DOS, Syed YS, Rajeev SK, Tony V (2017). Simultaneous saccharification and fermentation of pretreated Eucalyptus grandis under high solids loading. Ind Biotechnol 13:131-140
Shimizu FL, Monteiro PQ, Ghiraldi PHC, Melati RB, Pagnocca FC, Souza W, Sant'Anna C, Brienzo M (2018) Acid, alkali and peroxide pretreatments increase the cellulose accessibility and glucose yield of banana pseudostem. Ind Crop Prod 115:62-68

Suzuki K. Ojima T, Nishita K (2003) Purification and cDNA cloning of a cellulose from abalone Haliotis discus Hannai. Eur J Biochem 270:771-778

Trindade-Silva AE, Machado-Ferreira E, Senra MVX, Vizzoni VF, Yparraguirre LA, Leoncini O, Soares CAG (2009) Physiological traits if the symbiotic bacterium Teredinibacter turnerae isolated from the mangrove shipworm Neoteredo reynei. Genet Mol Biol 32:572-581

Turner RD (1996) A survey and illustrated catalogue of the Teredinidae (Mollusca: Bivalvia). The Museum of Comparative Zoology, Cambridge, $\mathrm{p} 265$

Wallace J, Brienzo M, Garcia-Aparicio M, Görgens J (2016) Lignin enrichment and enzyme deactivation as the root cause of enzymatic hydrolysis slowdown of steam pretreated sugarcane bagasse. New Biotechnol 33:361-371

Waterbury JB, Calloway CB, Turner RD (1983) A cellulolytic nitrogenfixing bacterium cultured from the gland of Deshayes in shipworm (Bivalvia, Teredinidae). Science 221:1401-1403

Xu P-N, Distel DL (2004) Purification and characterization of an endo$1,4-\beta$-D-glucanase from the cellulolytic system of the wood-boring marine mollusk Lyrodus pedicellatus (Bivalvia: Teredinidae). Mar Biol 144:947-953

Xu B, Janson JC, Sellos D (2001) Cloning and sequencing of a molluscan endo-beta-1,4-glucanase gene from the blue mussel, Mytilus edulis. Eur J Biochem 268:3718-3727

Yang JC, Madupu R, Durkin AS, Ekborg NA, Pedamallu CS, Hosteler JB, Radune D, Toms BS, Henrissat B, Coutinho PM, Schwarz S, Field L, Trindade-Silva AE, Soares CAG, Elshahawi S, Hanora A, Schmidt EW, Haygood MG, Posfai J, Benner J, Madinger C, Nove J, Anton B, Chaudhary K, Foster J, Holman A, Kumar S, Lesard PA, Luyten YA, Slatko B, Wood N, Wu B, Teplitski M, Mougous JD, Ward N, Eisen JA, Badger JH, Distel DL (2009). The complete genome of Teredinibacter turnerae T7901: an intracellular endosymbiotic of marine wood-boring bivalves (shipworms). PloS ONE 4:e6085

Zorec M, Vodovnik M, Marinsek-Logar R (2014) Potential of selected rumen bacteria for cellulose and hemicellulose degradation. Food Technol Biotechnol 52:210-221 